\title{
Personnel Flexibility and Red Tape in Public and Nonprofit Organizations: Distinctions due to Institutional and Political Accountability
}

\author{
Mary K. Feeney* \\ Assistant Professor of Public Administration \\ University of Illinois at Chicago \\ 412 S. Peoria St, CUPPA Hall 131 \\ Chicago, IL. 60607 \\ mkfeeney@uic.edu \\ (p) 312.355 .4734 \\ (f) 312-996-8804
}

\author{
Hal G. Rainey \\ Alumni Foundation Distinguished Professor \\ Department of Public Administration \& Policy \\ 204 Baldwin Hall \\ The University of Georgia \\ Athens, GA 30602-1615 \\ hgrainey@uga.edu \\ Phone: (706) 542-2979 \\ *Corresponding author
}




\title{
Personnel Flexibility and Red Tape in Public and Nonprofit Organizations: Distinctions due to Institutional and Political Accountability ${ }^{1}$
}

\begin{abstract}
Academics and journalists have depicted government bureaucracies as particularly subject to administrative constraints, including the infamous red tape and personnel rules that sharply constrain pay, promotion and dismissal and weaken their relations to performance. Research on these topics has often focused on public organizations alone or on comparisons of public and private organizations. The analysis reported here extends this research to include nonprofit organizations. Certain theoretical perspectives would predict sharp differences between public and nonprofit organizations, while others would predict no differences. Using survey data from managerial-level respondents in state government and nonprofit organizations in Georgia and Illinois, this analysis compares perceptions of red tape and personnel rule constraints in public and nonprofit organizations. We investigate whether or not public and nonprofit respondents differ in their perceptions about levels of organizational red tape, and about whether formal rules enable or constrain managers in promoting and rewarding good employees and removing poor performers. The results indicate sharp public and nonprofit differences, with public managers reporting higher perceived organizational red tape and lower levels of personnel flexibility. In addition to public and nonprofit comparisons, the analysis takes into account other factors that might influence public and nonprofit managers’ perceptions of red tape and personnel flexibility in their organizations, including individual motivations to choose the job, the respondent's state (Georgia or Illinois), and others.
\end{abstract}

\footnotetext{
${ }^{1}$ The authors would like to thank the anonymous reviewers who provided valuable suggestions and insights to further the development of the manuscript. The reviewers' thoughtful recommendations greatly improved this manuscript and the authors are greatful for their feedback.
} 


\section{Personnel Flexibility and Red Tape in Public and Nonprofit Organizations: Distinctions due to Institutional and Political Accountability}

\section{Introduction}

Historically, academics, journalists, and satirists have depicted government bureaucracies as particularly subject to administrative constraints, including "red tape” or burdensome rules and procedures that hinder performance. General red tape reduction initiatives in government have pursued this widely accepted view (e.g., Gore 1993). Major reforms have sought to eliminate red tape due to personnel rules because reformers contend that such rules constrain managers’ ability to reward or discipline employees. Convinced that rigid pay systems fail to reward good performance, reformers in governments around the world have sought to implement performance-based pay systems. After decades of such efforts, however, experts still emphasize the need for reform (Ballenstedt 2007), suggesting that previous reforms have had little effect in loosening the constraints (Ingraham 1993; Kellough and Lu 1993). In addition, as described below, survey research across decades has indicated that government managers are much more likely than managers in business firms to say that personnel rules make it hard to reward a good performer with higher pay and fire a poor performer.

This apparent persistence of red tape and constraining personnel rules across time and in spite of reform initiatives raises questions about why the constraints endure. These questions have implications for theories of public and nonprofit organizations. In this analysis we pursue

these implications by adding to the evidence not another comparison of government and business managers, but a comparison of public and nonprofit managers’ perceptions of red tape and personnel constraints. One possible theoretical perspective would posit that government oversight imposes red tape and constraining personnel rules. Business firms have more 
independence from government oversight in the United States and many other nations, because firms are purportedly governed by market forces such as competition and reliance on market sales for resources. Most government agencies do not sell outputs in competitive economic markets, so governmental authorities such as legislative bodies impose controls upon them, often in the form of constraining rules. This perspective predicts that public and nonprofit managers will differ in response to questions about red tape and personnel rule constraints. Nonprofit managers will be more like business managers, in that they operate with more autonomy from government oversight.

An alternative perspective predicts no differences between public and nonprofit managers, since they both operate in not-for-profit, public-serving contexts. The absence of profit as an incentive and source of information reduces decision-makers' incentive to maximize the efficiency of organizational structures and procedures through such steps as eliminating red tape and personnel rules. ${ }^{2}$ In addition, nonprofit status impedes the use of such motivating procedures as profit sharing. Both government and nonprofit organizations have value-laden missions that make performance goals harder to specify for use in such procedures as performance-based pay systems. Thus, most government and nonprofit organizations should be very similar because they usually share not-for-profit status.

The results reported below show strong support for the first perspective - public managers are much more likely to perceive higher levels of red tape, and lower levels of personnel flexibility (more difficulty rewarding a good performer with higher pay, more

\footnotetext{
${ }^{2}$ Economic property rights theorists contend that the absence of transferable ownership rights creates a fundamental distinction between business firms and government organizations (e.g. Alchian and Demsetz 1972; De Alessi 1980; see Bozeman 1987, 52 for further discussion). These theorists contend that absence of ownership and property rights for government organizations dilutes incentives for efficient organizational decisions, such as decisions to reduce red tape and enhance pay and disciplinary procedures. One can extend these theoretical postulates to nonprofit organizations, since no individual has a legal claim to personal control of the proceeds or property of a nonprofit organization. Hence incentives related to red tape and personnel rules should not differ between public and nonprofit organizations.
} 
difficulty in firing a weak performer, and a weaker linkage between rewards and performance). This finding comes from results of the third National Administrative Studies Project (NASP) survey (see Appendix I) to investigate three primary research questions: (1) Do managers and others in managerial-level positions in the public and nonprofit sectors differ in their perceptions of the levels of red tape in their organizations? (2) How do perceptions of personnel flexibility (a

measure of perceived constraints under personnel rules) vary between managers in the public and nonprofit sectors? (3) How convincing is this evidence? We take into account other responses on the survey that could influence such perceptions, such as individual motivations to choose a job, work history, demographic characteristics, organizational function/mission, and other variables in analyzing public and nonprofit managers' perceptions of red tape and personnel flexibility in their respective organizations.

\section{Literature and Hypotheses}

The question of whether public, nonprofit, and private organizations differ significantly in their characteristics has remained controversial and inconclusively resolved for many decades. The more specific question of whether the three types of organizations differ in levels of red tape and of personnel system constraints has followed a similar pattern, with practitioners and theorists adopting opposing stances.

Major developments in practice and public policy reflect the strong belief that government has too much red tape and too many personnel constraints, and more of these maladies than nongovernmental organizations. The Civil Service Reform Act of 1978, for example, sought to streamline procedures for dismissal. In various states in the U.S., reform legislation has loosened rules about firing, discipline, and pay and decentralized such decisions from central personnel agencies to the operating government agencies (Walters 2002). These 
reforms are driven in part by decades of sharp complaints from government managers and employees (Ballendstedt 2007; Macy 1971; Thompson and Rainey 2003). Often, the calls for reform include the assertion that government needs to adopt personnel rules and procedures similar to those in business. However, in striking contrast, government personnel administrators and experts have argued for decades that the claim that one cannot fire a bad government employee is a myth. They contend that an administrator can fire a bad government employee simply by following proper procedures (e.g., U.S. Office of Personnel Management 1999).

In the past, most disputes about whether government and business differ in levels of red tape and in personnel system constraints have often failed to consider the nonprofit sector. This omission requires attention, because government increasingly relies on the nonprofit sector administering government contracts and programs (Salamon 1998; Smith \& Lipsky 1993), including consistent increases in the number of nonprofits providing government services such as programs for children, the elderly, and the homeless, and public health and mental health programs (Feiock and Jang 2007). As the nonprofit sector expands to administer government goods and services and draws upon a similar, public-service minded workforce, it is increasingly important to understand distinctions between the public sector and the nonprofit sector, including differences in red tape and personnel flexibilities.

As for theoretical implications, they, too, involve diametrically opposing views. As pointed out earlier, one can make a theoretical case that government organizations differ from nonprofits due to government controls. One can also theorize that governments and nonprofits show no differences because they share nonprofit status. A generic tradition among organization theorists would also contend, through a different theoretical rationale, that a public versus nonprofit distinction predicts no significant differences among organizations. This perspective 
condemns distinctions such as public versus private and profit versus nonprofit as crude stereotypes. Instead, the generic commonalities among organizations warrant more attention than such crude distinctions (e.g., Thompson 1962). Where there are differences among organizations, they are better explained by differences in such factors as technology, task, and size, rather than by public, nonprofit, or private status. One can cite no stronger expression of this perspective than an observation from Nobel Laureate Herbert Simon. Discussing economic rewards in organizations, Simon stated bluntly that, “...Everything said here about economic rewards applies equally to privately owned, nonprofit, and government-owned organizations. The opportunity for, and limits on, the use of rewards to motivate activities towards organizational goals are precisely the same in all three kinds of organizations...” (1995, 283, footnote 3). Simon, the preeminent behavioral scientist ever to study organizations, thus forcefully asserts that reward systems (which include the personnel rules governing them) are "precisely the same" in public, nonprofit, and private organizations.

Simon's observation is obviously quite at odds with the views of reformers and experts described earlier, and its theoretical implications are enormous. Should a theory of public and nonprofit organizations posit that civil service systems and "system-wide rules” (Warwick 1975, 162) produce no difference in personnel rules and red tape among government, nonprofit, and business organizations?

For many years administrative theorists in political science and economics have contended that government organizations tend toward high levels of rules, red tape and personnel constraints than business firms (e.g., Dahl and Lindblom 1953, 458; Downs 1967, 59; Warwick 1975, 162; Wilson 1989, 120-121). Theoretical explanations for the higher incidence of red tape often assert that political authorities exercise much more oversight over government agencies 
than over nongovernmental organizations. In the absence of market-provided information such as sales and profits government authorities emphasize compliance with rules and procedures to assure accountability and performance. Others emphasize accountability pressures in government that reduce incentives and opportunities to streamline administrative procedures and to reduce red tape. This theoretical orientation depicts government auspices as a distinctive context for organizations.

These ongoing disagreements show the need for more evidence. Boyne (2002), in reviewing studies comparing survey responses of public and private respondents, points out that many of the published studies analyze results of the same surveys. There are even fewer direct comparisons of public and nonprofit organizations. The situation points to the need for more studies with different samples, including more large sample empirical research comparing “sectors” on personnel dimensions and expanding to include nonprofit organizations. More comparisons between the public and nonprofit sectors can add evidence about institutional distinctions such as the presence or absence of profit indicators, motivations, and incentives. If we find differences between government and private nonprofit organizations that resemble the differences researchers have found between government and private for-profit organizations, this provides evidence that the differences may not derive from the presence or absence of a profit indicator and incentive. Rather, this would provide evidence that public versus nonprofit differences result from other institutional distinctions, such as the presence or absence of governmental ownership, oversight and personnel structures.

\section{Research on Red Tape and Personnel Rule Constraints}

In recent years, serious analysis of red tape (Bozeman 2000) has led to empirical examination and improved conceptualization. For example, Pandey and Scott (2002) have shown evidence 
that managers' responses about red tape differ from their responses on formalization measures, which organizational researchers use to measure the general intensity of formal rules and procedures, as opposed to the unduly constraining effects of red tape. Researchers have shown evidence that measures of general organizational red tape, including the one used in the present study, relate to such factors as alienation (Dehart-Davis and Pandey 2005), public service motivation (Scott and Pandey 2005), and, in complex ways, to performance (Brewer and Walker 2005), as well as to other variables.

In comparing public and private managers, researchers have found large differences in the way the two groups of managers responded to questions about red tape, and whether their organization's personnel rules constrain pay and dismissal. Other studies have found that public managers perceive higher levels of red tape in personnel rules (Baldwin 1990; Bozeman and Bretschneider 1994; DeHart-Davis and Pandey 2005), information red tape (Baldwin 1990), and red tape as a delay in task completion (Bretschneider 1990). These results are very consistent with studies of public and private managers' perceptions about the constraining effects of personnel rules on dismissal of poor performers and on rewarding good performers with higher pay. The studies individually have limited samples, but together show striking consistency in their support for differences between public and private managers. Rainey (1983), for example, reported that a sample of federal and state government middle managers in Ohio differed sharply from middle managers in Ohio business firms, on questions about personnel flexibility (i.e. absence of constraints on tying pay and dismissal to performance). Later, in the early 1990s a survey in the Syracuse, New York area found similar differences between large and diverse samples of government and business managers, on the same questions (Rainey, Pandey, and Bozeman 1995). Table 1 shows the mean scores for two of the questions from these surveys: (1) 
Even if a manager is a poor performer, formal rules make it hard to remove him or her from the organization and (2) The formal pay structures and rules make it hard to reward a good manager with higher pay here. Also indicated on table 1 are additional surveys administered in Florida and Denver (Moon and Bretschneider 2002; Rainey et al. 1995).

[Table 1 about here]

Table 1 indicates that public sector respondents compared to private sector respondents consistently expressed more agreement with the two statements. Table 2 provides a more straightforward look at the sharp differences. In the Ohio survey, over eighty percent of the public managers felt that the statements about constraints on higher pay and about the difficulty in firing were true, while much smaller percentages of private business managers said the statement was true. In the New York survey, about 15 years later, nearly ninety percent of the public managers agreed that it is hard to remove a poor manager and reward a good manager with higher pay, compared to very small percentages of the business managers who agreed. These differences remained large even when taking into account numerous control variables.

[Table 2 about here]

These strong findings come from samples representing different levels of government, government agencies and business firms, geographic regions, and time periods. Quite significantly, they contrast sharply with Nobel Laureate Herbert Simon's aggressive claims about reward conditions being "precisely the same" in government, business, and nonprofit organizations. Still, given the vastness and complexity of the three "sectors," these surveys offer limited evidence. Further studies can provide evidence about the generalizability and durability of such findings. The comparison of a public and a nonprofit sample in the current study provides evidence about whether the differences will be similarly strong. 


\section{Nonprofit Organizations: Relevant Research}

While there are very few direct comparisons of public and nonprofit organizations on red tape and flexibility of personnel procedures (Lan and Rainey 1992), there is research on nonprofit organizations relevant to this topic. As do public organizations, private nonprofit organizations pursue public missions without providing financial gains to stockholders or individual owners. Nonprofit organizations balance public and private interests, often engage in activities similar to those of government organizations (e.g. health care, education, social services, and disaster relief), but operate apart from the control of the market and the state (Anheier and Seibel 1990) and outside of the constraints of government personnel systems.

Increasing interest in research comparing government and private nonprofit work environments has led to diverse findings that indicate similarities, but also important differences in attitudes, motives, and perceptions in the two workforces. For example, research indicates that nonprofit workers report higher job commitment compared to public sector employees (Borzaga and Tortia 2006; Light, 2002; Mirvis and Hackett 1983). On the other hand, studies have found that that both public and nonprofit workers are public service-minded (Rotolo and Wilson 2006) and place greater importance on personal relations than workers in the private for-profit sector (Rawls et al. 1975).

Although research indicates that nonprofits share some similarities with public organizations, such as dependence on external sponsors (Corder 2001) and level of managerial professionalism (Berman and West 1998), nonprofit organizations do not operate within civil service systems. Such distinctions lead to claims that nonprofits are more flexible and responsive than many government institutions (e.g., Hall 1992). Nonprofit organizations manage a complex labor force composed of paid and volunteer staff (Brudney 1998a, 1998b; Weisbord 1997) and 
must negotiate their personnel policies with boards of directors and funders (Corder 2001; Hall 1992; Weisbrod 1988). Observers nevertheless, contend that nonprofit organizations generally operate under more flexible rules and fewer constraints than government organizations (Eggleston and Zeckhauser 2002; Hall 1992), but are these claims true? Nonprofit organizations do face challenges and constraints due to external controls and multiple stakeholders including boards, trustees, service recipients, volunteer and paid labor, and government and corporate investors (Salamon 1998). Some studies have found that personnel rules in nonprofit organizations are not as highly formalized as in government organizations (Kalleberg et al. 2006), but formalization is distinct from red tape and constraining personnel rules that we analyze in the current study (Pandey and Scott 2002; Welch and Pandey 2007). In general, red tape researchers note a distinction between formalization and red tape - formalization is neutral, whereas red tape is negative (Bozeman 2000; Bozeman \& Kingsley 1998; Bozeman \& Scott 1996; Pandey \& Scott 2002). ${ }^{3}$

Some researchers argue that sector differences are narrowing as nonprofit and public organizations become more commercial and businesslike (Kettl 1993; Weisbrod 1988). This makes it all the more important to analyze whether this narrowing might be taking place, and what differences it may be making. For example, if this narrowing is having substantial effects we should find that managers in state government and nonprofit organizations do not differ in their perceptions of red tape and hiring, firing, and promotion systems, taking into account the

\footnotetext{
${ }^{3}$ Formalization is defined as "the extent to which rules, procedures, instructions and communications are written" (Pugh, et al., 1969: 75). Red tape, in contrast, is defined as rules, regulations, and procedures that have a compliance burden but do not achieve the functional objective of the rule (Bozeman 2000). Red tape is inefficient and has negative outcomes - there is no such thing as good red tape. It is possible that highly formalized organizations have low levels of red tape and organizations with weak internal controls can have high levels of red tape (Bozeman and Loveless 1987). Welch and Pandey (2007) offer a methodological test that red tape and formalization are different concepts, and conclude that although formalization is positively associated with general organizational red tape it is not a significant determinant of procurement red tape. Thus, while formalization and red tape are both concerned with rules, regulations and procedures, they remain distinct concepts.
} 
possibility that public and nonprofit organizations attract, select, and retain different types of people (Harpaz and Snir 2003; Schneider 1987; Schneider et al. 1995)? On the other hand, research indicates that most of the factors that increase red tape in the public sector are external sources such as govenment civil service and purchasing systems that should be independent of the alleged narrowing described above (Bozeman and Bretschneider 1994; Brewer and Walker 2006). We hypothesize that nonprofit managers, who are not subject to civil service protections and restraints, will report more personnel flexibility in their organizations, compared to public managers.

H1a: Perceptions of organizational red tape vary between employees in the public and nonprofit sectors.

H1b: Public managers compared to nonprofit managers will report higher organizational red tape.

H2a: Perceptions of personnel flexibility vary between employees in the public and nonprofit sectors.

H2b: Nonprofit managers compared to public managers will report higher personnel flexibility.

Since this is the first study comparing nonprofit and state government managers' perceptions of red tape and personnel flexibility we need to eliminate as many alternative interpretations of the findings as possible. Perceptions of red tape and personnel rules can relate to other factors besides the public versus nonprofit distinction. Hence we take into account factors such as the respondents' motivations to choose their current jobs, because selection into a job and sector may relate to respondent perceptions of red tape and personnel flexibility.

In addition, previous research indicates that a person's desires for extrinsic rewards (e.g. increased salary and benefits) and intrinsic rewards (e.g. feelings of accomplishment and a desire to serve the public) are related to the person's perceptions and attitudes about the organization in 
which she or he works. Researchers have investigated the motivations and values related to selecting work in a particular sector (Jurkiewickz et al. 1998; Lyons et al. 2006; Mirvis and Hackett 1983), including public service motivation (e.g., Perry and Hondeghem 2008a, 2008b), a desire for job security, the opportunity for equal opportunity hiring, and the need to control the amount of time spent at work (Izraeli 1990). Both nonprofit and public sector employees report higher intrinsic rewards than those in for-profit organizations and a lower likelihood of receiving extrinsic rewards such as increased pay or promotion (Mirvis and Hackett 1983; Wittmer and Coursey 1996). Workers in the nonprofit sector, compared to the for profit sector, are more people oriented (Rawls et al. 1975) and care more about serving the public interest (Wittmer and Coursey 1996) and advancing the organization’s public service mission (Light 2002). In comparison, some research indicates that public sector workers value opportunities for advancement and intellectually stimulating and challenging work more than nonprofit workers (Crewson 1995, 94; Lyons et al. 2006). These diverse findings suggest that public managers and employees might differ from nonprofit comparison groups on attitudes and perceptions that might influence perceptions about red tape and personnel rules, and hence need to be taken into account in our analysis.

There is a great deal of research investigating work life and motivation among public, nonprofit, and for-profit private sector workers (e.g., Balfour and Wechsler 1990, 1991; Light 2002; Steinhaus and Perry 1996). People who are interested in job security may have a higher tolerance for red tape and personnel rules and restrictions. Those driven by a desire for career advancement may have strong negative perceptions about personnel inflexibilities especially when those personnel restrictions impede promotion and advancement. Individuals driven by a desire to serve the public interest may tolerate higher levels of personnel restrictions (Scott and 
Pandey 2005) or they may resent them as an impediment to the organization’s mission

(Moynihan and Pandey 2007). Given the variations in research on work life by sector, we predict that motivations for selecting a job in the public or nonprofit sector (public service motivation and a desire for job security, career advancement, and financial benefits) will be related to perceptions of red tape and personnel flexibility.

H3a: Individual motivations for selecting a public or nonprofit sector position are related to managers' perceptions of red tape in their respective sectors.

H3b: Individual motivations for selecting a public or nonprofit sector position are related to managers' perceptions of personnel flexibility in their respective sectors.

Public and nonprofit organizations can also differ in the external institutional context in which they operate, and we represent such variations by comparing respondents from Illinois to respondents from Georgia. We expect to find variation across states in perceptions of red tape and personnel flexibility for both nonprofit and state managers. First we expect that perceptions of rule flexibility will differ between managers in Georgia and Illinois due to state government human resource reforms. Georgia underwent reforms in the late 1990s that have resulted in about 72\% of Georgia state government employees being at-will-employees. The Georgia reforms also included a pay-for-performance initiative aimed at tightening the linkage between pay raises and performance evaluations. In addition, Georgia restricts the number of issues open to grievances more than Illinois (Hays and Sowa 2006). Illinois’ public sector has not expanded its at-willemployment beyond its standard $20 \%$ of the workforce and continues to offer a wide range of issues open to grievances. We expect that the expansion of at-will hiring in Georgia will drive lower perceptions of red tape and more positive views of personnel flexibilities compared to perceptions among Illinois state managers. 
We also analyze organizations by state. State-level regulation of nonprofit organizations varies across states in reporting requirements, state laws, tax codes, and tort law (Irvin 2005). State regulation of nonprofit organizations in Georgia and Illinois creates conditions that should influence employees’ perceptions. Differences in state regulations over nonprofits and in state government human resource reforms lead us to expect that perceptions of red tape and personnel flexibilities in nonprofit and public organizations will vary by state.

H4a: Perceptions of red tape will vary by state.

H4b: Perceptions of personnel flexibility will vary by state.

\section{Data and Methods}

This study analyzes data from the NASP-III questionnaire, which was administered to a random sample of 1849 public managers (and professionals and technicians working in managerial-level positions) and 1307 nonprofit managers (including managerial-level professionals and technicians) in Georgia and Illinois from organizations performing numerous functions. ${ }^{4}$ The survey was closed in January 2006 with 1220 respondents, 790 from the public sector and 430 from the nonprofit sector. The overall response rate is 39\% (43\% for the public sector and 33\% for the nonprofit sector). Fifty-five percent of the public sector respondents and one quarter of the respondents from the nonprofit sector work in Georgia. Although this response rate is lower than previous NASP studies, it is not surprising inasmuch as public sector respondents regularly respond at higher rates than those in private and nonprofit organizations. Unlike other public sector surveys, NASP III was administered without the assistance of state government and

\footnotetext{
${ }^{4}$ NASP III included respondents from 102 public agencies and 306 nonprofit organizations. The organization names are too numerous to enumerate here, but include organizations in areas of public safety, natural resources, social services, education, housing, animal protection, environment, agriculture, telecommunications, human resources, law, finance, taxation, industry, science, research, health and medicine, commerce, utilities, architecture, building and real estate, engineering, tourism, and the arts. For a full list of the organization functions, please see the NASP III codebook available at http://www.uga.edu/padp/nasp.html.
} 
agency heads or managers. Previous studies have found that high-ranking individuals in nonprofit organizations are less likely to respond to surveys. The response rate remains higher than average response rates in general surveys of organizational employees (Kanuk and Berenson 1975). See Appendix I for details about the study approach and Appendix II for descriptive statistics.

Dependent Variables. The first dependent variable is a general scale of organizational red tape. The Red Tape Scale is measured using responses to the following question: "If red tape is defined as 'burdensome administrative rules and procedures that have negative effects on the organization's effectiveness,' how would you assess the level of red tape in your organization?” Please circle the appropriate response between 0 and 10, with 0 indicating "Almost No Red Tape” and 10 indicating “Great Deal of Red Tape”. Researchers have often used this item (e.g. DeHart-Davis 2007; Welch and Pandey 2007). The Red Tape Scale has a mean of 6.03 and a standard deviation of 2.683 .

Second, we use three items to measure personnel flexibility. The survey asked respondents to indicate their level of agreement with the following three statements about their organization's formal rules related to promotion, rewards, and dismissal. ${ }^{5}$

1. Because of the rules here, promotions are based mainly on performance. (Performancebased Promotions)

2. Even if a manager is a poor performer, formal rules make it hard to remove him or her from the organization. (Performance-based Removal)

3. The formal pay structures and rules make it hard to reward a good employee with higher pay here. (Performance-based Rewards)

The three items, respectively named Performance-based Promotions, Performance-based Removal and Performance-based Rewards are similar to those used in the research described

\footnotetext{
${ }^{5}$ The response categories were a four point likert scale (4=strongly agree, $3=$ somewhat agree, $2=$ somewhat disagree, $1=$ strongly disagree).
} 
earlier (DeHart-Davis and Pandey 2005; Pandey and Moynihan 2006; Pandey and Welch 2005; Rainey 1983; Rainey et al. 1995; Scott and Pandey 2005), and in more recent research (Boyne, Brewer, and Walker 2006; Brewer and Walker 2005, 2006). Brewer and Walker (2005) describe the first two personnel flexibility items as measures of personnel red tape and use these items as both separate independent variables (2005) and as a summed index dependent variable (2006). DeHart-Davis and Pandey (2005) and Pandey and Welch (2005) combine Performance-based Removal and Performance-based Rewards plus two additional items to create a variable that they call human resources red tape. Our third item, Performance-based Rewards, is distinct from previous uses, in that it asks about the ability to reward a good employee, not just a manager.

We ran a principal components factor analysis on the three personnel flexibility items (see table 3). The three items load on a single factor, with an initial eigenvalue of 1.795 . The principal components analysis suggests that the three items are strongly correlated and measuring a shared underlying concept, thus we created an index by summing the three items.

Independent Variables. We use a dummy variable, Nonprofit, to test for variation in perceptions of personnel rules by sector. Nonprofit is coded one if the respondent works in the nonprofit sector ( $0=$ respondent works in the public sector).

We include four variables measuring the reasons a respondent took the current position: Career Advancement Motivation, Financial Motivation, Job Security Motivation, and Public Service Motivation. NASP-III asks respondents to respond to the following directive, "We are interested in the factors that motivated you to accept a job at your current organization. Please indicate the extent to which the factors below (some personal, some family, and some professional) were important in making your decision to take a job at your current 
organization. ${ }^{\prime 6}$ The variables Financial Motivation and Desire to Serve the Public are based on

responses to the questionnaire items Salary and Ability to serve the public and the public interest, respectively. Security Motivation and Career Advancement Motivation are saved factor scores

from a factor analysis using an orthogonal solution and Varimax rotation of the following items:

- Opportunity for advancement within the organization's hierarchy

- The organization's pension or retirement plan

- Desire for increased responsibility

- Benefits (medical, insurance)

- Few, if any, alternative job offers

The factor analysis resulted in two dimensions: security and advancement, which

represent $63 \%$ of the common variance in the initial correlation matrix. Table 4 presents the

factor loadings matrix. The motivation measures help to capture the relationship between

personality and work behavior.

We include a dummy variable, Georgia, coded one if the respondent works in Georgia, to

test the final hypotheses, which predict variation in perceptions of personnel flexibility by state.

Controls. ${ }^{7}$ Because research (Dodd-McCue and Wright 1996) indicates that workplace

experiences and job tenure (Buchanan 1975) shape workplace commitment and attitudes, we

\footnotetext{
${ }^{6}$ Job choice motivation factors included: Job Security, Salary, Ability to serve the public and the public interest, The organization's pension or retirement plan, Desire for increased responsibility, Opportunity for advancement within the organization's hierarchy, Benefits (medical, insurance), and Few, if any, alternative job offers. Response options were a four point Likert scale: very important, somewhat important, somewhat unimportant, and not at all important. ${ }^{7}$ A reviewer of this article raised the interesting and important question of whether the "publicness" of a nonprofit organization (Bozeman 1987), and in particular the "financial publicness" (the level of funding from government) could explain similarities between nonprofit and public organizations. As nonprofits receive more government funding through contracts and grants, will their personnel rules and procedures become more like those of government organizations? The reviewer suggested that this possibility makes it important for us to control for financial publicness. Our data do not allow us to control for this variable, but the present analysis remains valuable without this control. The available evidence suggests that financial publicness should not have strong effects on the personnel flexibility variables in our study. Bozeman and Bretschneider (1994) compared financial publicness and "core public versus private" (a public versus private distinction) as predictors of personnel constraints and other dependent variables in R\&D labs. They found that financial publicness related significantly to such variables as the types of products a research and development organization produced, but it showed no significant relationship to personnel constraints. Core publicness, on the other hand, showed highly significant relations to personnel system constraints. This indicates that presence or absence of a civil service system, which usually comes with "public" status, is more influential on personnel system characteristics than financial publicness. This important question
} 
include the following variables to control for aspects of the respondent's work environment and experiences which may shape perceptions of personnel flexibility: Current Job Tenure, Job Position: Manager, Manager*Tenure, and Promotion. Current Job Tenure is a continuous variable measuring the number of years the respondent has worked in her current position. Current Job Position: Manager is a dummy variable coded one if the respondent's main responsibility is managerial (some of the respondents were managerial-level professionals and technicians). The control variables Current Job Position: Manager and Current Job Tenure are proxies for salary and seniority (Bridges and Villamez 1994). We also include an interaction variable for manager and tenure at the current job, Manager*Tenure. The variable, Promotion, is a dummy variable coded one if the respondent's current job was a promotion. ${ }^{8}$

Research indicates the need to take into account previous work experiences because such experiences can shape perceptions of a current work environment (e.g., Dodd-McCue and Wright 1996). Experiences in one sector affect work behavior and perceptions when an individual switches sectors (Feeney 2008; de Graaf and Van der Wal 2008). Feeney (2008) finds that previous private sector work experience shapes public managers' perceptions of the public and nonprofit sectors and Boardman and colleagues (in press) find that public managers with private sector work experience have significantly different work attitudes compared to those who have spent their entire careers in the public sector. We use a dummy variable, Private, to control

merits further attention in future research. In addition, if financial publicness is making nonprofit organizations more like public organizations, this makes our public versus nonprofit comparison more stringent. We should be less likely to find the difference that we report in this study.

${ }^{8}$ It is possible that in some cases the current job was a demotion. Because demotions are uncommon in the public sector, we did not ask for this information. Furthermore, we felt any small amount of additional information gained would be at too great a price in terms of diminishing rapport with the respondent. 
for previous private sector work experience. Private is coded one if the respondent's previous job was in the private sector. ${ }^{9}$

We also control for the respondent's activities outside of the workplace. Total Civic Activities is an additive index of responses to a series of dummy variables listing organizations or groups to which the respondent might belong. Total Civic Activities, ranging from zero to eight, is an indication of the respondent's involvement in non-work organizations.

Previous research (Rainey et al. 1995) finds that organizational size is significantly related to perceptions of red tape among public and private managers. Org. Size is a continuous variable indicating the number of full time employees in each respondent's organization. We also conducted analyses of the relationships between organizational function and the dependent variables and found that organizational function did not significantly affect the model or results (See Appendix III). ${ }^{10}$ Finally we control for demographic characteristics, which may shape public and nonprofit managers' perceptions of red tape and personnel flexibility. Since many hiring preference programs have been designed with women and minorities in mind, female and nonwhite respondents may be more accepting of personnel restrictions, which they may see as protecting their interests and jobs. Female is coded one if the respondent is female. Age is a continuous variable. Nonwhite is coded one if the respondent self-reported any race other than white/Caucasian.

\footnotetext{
${ }^{9}$ We also tested variables that indicate if the respondent's previous job was in private, nonprofit, and public sectors, tenure in the private sector, nonprofit, and public sectors, and if the current job was a sector switch.

${ }^{10}$ We considered the possibility that organizational function is related to perceived red tape and personnel flexibility. The sample was drawn from about 306 nonprofit organizations and 103 state agencies. These organizations vary in type, mission, and size. We coded the organization data into 15 functional types of organizations. We ran the models first with a single categorical variable for organizational type and then with a set of 15 dummy variables. The organizational function variables were not significant in any of the models and did not significantly affect the relationships between the other variables or the model specificity. We include a table in Appendix III, which shows the mean responses for the rules items, by organizational function.
} 
We use an OLS regression model to predict the red tape scale and the personnel flexibility index. In addition to the models predicting the dependent variables with sector as an independent variable, we ran separate models for the public and nonprofit groups. When we control for sector, with a single independent variable, all the variance between nonprofit and public sector respondents falls into the intercept. By splitting the sample, we allow each independent variable and the outcomes to vary by sector and are able to assess how these relationships vary for individuals selecting into the public sector as compared to those selecting the nonprofit sector. The separate models for public and nonprofit managers can provide significantly different beta estimates on the independent variables, giving a more detailed understanding of how the relationships between all of the variables differ by sector.

\section{Results}

We examine perceptions of red tape and the flexibility of personnel structures in the public and nonprofit sectors discussing the results for all of the models in order of the four hypotheses, followed by a discussion of the control variables. The results are presented in tables 5, 6 and 7 .

[Tables 5, 6 and 7 about here]

A first step in this analysis examines whether respondents in the two sectors differ significantly in their perceptions of red tape and personnel flexibility. The model predicting the perception of Organizational Red Tape confirms H1a and H1b (table 6). Respondents who work in the nonprofit sector report significantly lower levels of organizational red tape compared to public sector workers. Working in the nonprofit sector is related to a nearly three point lower ranking of red tape, as compared to working in the public sector.

To test our second hypotheses on personnel flexibility (H2a and H2b), we compared the mean scores by sector for the entire sample on the three rules items (table 5). Respondents 
working in the public sector are significantly more likely than nonprofit respondents to agree that formal rules make it hard to remove a poorly performing manager and to reward a good manager with higher pay. Nonprofit respondents on average report significantly more agreement that because of organization rules promotions are based mainly on performance. The comparison of means in table 5 confirms H2a and H2b; perceptions of personnel flexibility vary between employees in the public and nonprofit sectors and nonprofit managers, compared to public managers, report more flexibility to remove and reward based on performance. Table 7 further indicates that the public versus nonprofit distinction relates significantly to the personnel flexibility index, with nonprofit respondents reporting more personnel flexibility. Respondents from public organizations perceive that the rules place stronger constraints on dismissal, tying pay to good performance, and tying promotion to performance.

By testing the outcomes for the full sample and the split models, we are able to see the strength of the variable indicating whether the respondent works in the public or nonprofit sector. For example, in the model predicting organizational red tape for the full sample the adjusted $\mathrm{R}$ squared is .337. When we split the model the adjusted R squared for the nonprofit sector is .176 and for the public sector 0.078. In practical terms, the full model, with a variable indicating sector explains nearly $34 \%$ of the variance in red tape perceptions, whereas the variables in the nonprofit model explain $17.6 \%$ and in the public sector model a mere $7.8 \%$. We find similar explanatory power in the models predicting personnel flexibility, with the split models predicting $15.4 \%$ and $17 \%$ of the variance in the nonprofit and public samples, respectively, but the full model (including a variable for sector) explaining $47 \%$ of the variance in the dependent variable. Thus, sector is a strong predictor of variance in red tape perceptions and personnel flexibility. 
The OLS models enable us to investigate the remaining hypotheses about the relationships between perceptions of red tape, personnel flexibilities, work motivations, and state (Illinois versus Georgia). First, we find some support for hypothesis 3a, about security motivation and career advancement motivation and red tape perceptions. Respondents who report higher desire for job security as a motivation for taking their current job report higher perceptions of red tape in their organizations. Conversely, those who took their current job with a desire for career advancement report lower perceptions of red tape.

When we split the model by sector, we see that nonprofit respondents with a stronger desire for job security report significantly higher perceptions of red tape as compared to nonprofit respondents with lower desires for job security. Meanwhile, public sector respondents who report that career advancement was an important motivator for taking the job have significantly lower perceptions of red tape. In the public sector model, we find no significant relationships between a desire to serve the public and salary as a motivation for taking the current position and perceptions of red tape. With regard to perceptions of personnel flexibility, among public managers career advancement and job security motivation are not significantly related to perceived personnel constraints. However, public managers who report a lower desire to serve the public report fewer personnel constraints. Thus, we find mixed support for our second hypothesis that individual motivation for selecting a public or nonprofit sector position shape managers' perceptions of personnel flexibility in their respective sectors. We confirm a relationship between a desire for job security and for promotion and perceptions of personnel flexibility.

Our models confirm hypotheses $4 \mathrm{a}$ and $4 \mathrm{~b}$ and indicate that working in Georgia is significantly and negatively related to perceptions of red tape and personnel constraints. 
Respondents in Georgia report significantly lower perceptions of red tape compared to respondents in Illinois. This finding holds for the split models as well. Being a nonprofit manager in Georgia, as compared to Illinois, is significantly related to a 1.181 lower rating of perceived organizational red tape. Similarly, respondents in the public sector in Georgia report significantly lower organizational red tape than their Illinois counterparts. Respondents in Georgia, as compared to Illinois, also report higher levels of perceived personnel flexibility. Respondents from Illinois, in both the public and nonprofit sectors, report higher personnel constraints than their respective Georgia counterparts. This finding supports the conclusion that external institutional context can influence the dependent variables, and confirms the need to take such factors into account.

Next, we turn to the control variables in these models. Being a manager and reporting that the current job was a promotion are both negatively related to perceptions of personnel constraints in the work place but not significantly related to general perceptions of red tape in the full models. By splitting the nonprofit and public sector respondents, we see that the negative relationship of being a manager and being promoted to perceptions of personnel constraints holds for public sector employees, but not for nonprofit respondents. Respondents who are public managers, compared to professionals, technicians, and other higher-ranking non-managers in the public sector, are significantly more likely to report lower personnel flexibilities.

We now turn to the relationships between previous work experience in the private sector and perceptions of red tape and personnel restrictions and flexibilities. We find no relationships between previous work experience in the private sector and perceived red tape and personnel flexibilities. The split models (table 7) show that nonprofit respondents whose previous position was in the private sector are significantly more likely to report higher perceived personnel 
constraints in the current position, as compared to nonprofit respondents who had not previously worked in the private sector.

Finally, although we find no significant relationships between gender and perceptions of red tape and personnel flexibility, we find that nonwhite respondents compared to white respondents report significantly lower perceptions of red tape and among nonprofit respondents, white respondents report significantly higher personnel constraints than nonwhite respondents.

\section{Discussion and Conclusions}

In the last few decades, empirical research investigating public and private sector distinctions has indicated that the public sector has a distinct set of constraints, rules, and red tape related to personnel procedures (Baldwin 1990; Bozeman and Bretschneider 1994; Brewer and Walker 2005, 2006; Kalleberg et al. 2006; Lan and Rainey 1992; Rainey et al. 1995). The research that we report here extends our understanding of sector distinctions by comparing public and nonprofit managers' perceptions of red tape and personnel flexibilities. We find that state government managers, compared to nonprofit managers, are significantly more likely to report higher levels or red tape and less flexible personnel rules and regulations.

We find that the state where the respondent is employed, Georgia compared to Illinois, is significantly related to perceptions of red tape and personnel flexibilities. Respondents working in Georgia perceive significantly lower levels of red tape and higher levels of personnel flexibility compared to respondents in Illinois. These differences in perceptions of rules and constraints appear to be due to personnel reforms in Georgia or the presence of unions in Illinois, or both. Factors that can influence such perceptions, including strength of unions in different states and differences in administrative culture need attention in future research. 
We find that when controlling for sector, there remains significant variation in red tape perceptions related to reporting that the current job was chosen due to a motivation for career advancement (negative) and security (positive). This finding makes sense, if we think of red tape and personnel constraints as providing job security and also possibly rewarding job tenure. Those individuals seeking career advancement will seek positions in organizations with less red tape and personnel constraints. Similarly, it makes sense that people seeking job security will choose positions in organizations with more personnel rules and regulations protecting jobs.

We find no significant relationships between previous private sector work experience and general red tape. Nonprofit respondents, whose previous job was in the private sector, report increased perceived personnel constraints. It is possible that these "sector switchers" are selfselected individuals who move from the private sector to the public and nonprofit sectors for mission reasons and are not significantly disturbed by organizational red tape.

Given the growth of the nonprofit sector in the last decades and the increasing competition between the public and nonprofit sectors for talented public service-minded managers, understanding the distinctions between these sectors will continue to be important to public management scholars. Moreover, this research extends findings from previous surveys (table 1) about personnel rules and constraints by comparing public and nonprofit managers.

Sector based variation in perceived red tape and the personnel flexibility items are important because they point to the personnel distinctions between these mission-driven sectors. Previous research indicates that perceptions of red tape dampen risk-taking among city-level public managers (Feeney \& DeHart-Davis 2009) and negatively affect public managers’ organizational commitment, job satisfaction, and psychological attachment to their workplace and morale (DeHart-Davis and Pandey 2005). Furthermore, research focused on personnel 
flexibility finds that perceptions about the ability to reward a good manager is significantly related to governmental performance and that burdensome rules and regulations lower individual and organizational performance in government (Pandey and Moynihan 2006; Brewer and Walker 2005). At the same time, previous studies have reported evidence that some public managers who perceive personnel constraints in their organizations actually regard those constraints as a necessary aspect of administration in the public sector, valuable as defenses against political intrusions, among other justifications (Rainey 1983). As public service professionals choose between service through government or private not-for-profit organizations, it is important to understand variation caused by personnel constraints and efforts to ensure institutional and political accountability.

Although one should be cautious in generalizing from one study, the evidence provided here can contribute to theory development for public and nonprofit organizations. It adds to a stream of studies finding differences in respondents' perceptions of personnel systems in public and private organizations, and now private nonprofit organizations. These differences - even in a state that has reformed its personnel system to try to diminish or remove them - suggest that government organizations inherently tend towards more formalized and constrained personnel systems as compared to both private and nonprofit organizations. This theoretical proposition can be further developed and tested in future research that should include more analysis of relations between managers' perceptions of personnel system characteristics and other matters such as the appropriateness of constraints. Future research needs also to strive for more evidence of the relations between personnel system characteristics and individual and organizational performance. Policy implications of the evidence here include the indication that public officials seeking to contract with the nonprofit sector in pursuit of greater personnel flexibilities will find 
evidence in the present study that such an objective is justified. One might argue that the nonprofitization of the public sector will free government from personnel constraints. On the other hand, outsourcing to nonprofits may remove public programs and services from important rules and regulations that ensure accountability and protect employees. The evidence presented here indicates that even though both types of organizations are not-for profit and provide public services, public and nonprofit organizations nevertheless show sharp distinctions in red tape and personnel flexibility. Thus, while the evidence here comes from one study with obvious limitations, it can contribute valuably to policy decisions and to theory development for public and nonprofit organizations. 
Table 1: Mean Scores for Flexibility of Personnel Measures: Comparing NASP-III and Previous NASP Studies

\begin{tabular}{|c|c|c|c|c|c|}
\hline & $\begin{array}{l}\text { Mean } \\
\text { Public }\end{array}$ & $\begin{array}{c}\text { Mean } \\
\text { Private } \\
\end{array}$ & $\begin{array}{c}\text { Mean } \\
\text { Nonprofit }\end{array}$ & $\begin{array}{c}\text { Sig. } \\
\text { Level }\end{array}$ & Eta2 \\
\hline \multicolumn{6}{|c|}{$\begin{array}{l}\text { Even if a manager is a poor performer, formal rules make it hard to remove him } \\
\text { or her from the organization. }\end{array}$} \\
\hline New York Survey & 1.88 & 3.41 & & 0.0000 & 0.4478 \\
\hline Florida Survey & 2.59 & 3.36 & & 0.0001 & 0.1138 \\
\hline Denver Survey & 2.10 & 3.07 & & 0.0000 & 0.3281 \\
\hline NASP III & 2.04 & & 3.03 & 0.0000 & 0.214 \\
\hline Illinois Survey & 1.90 & & 2.93 & 0.0000 & 0.249 \\
\hline Georgia Survey & 2.16 & & 3.34 & 0.0000 & 0.215 \\
\hline \multicolumn{6}{|c|}{$\begin{array}{l}\text { The formal pay structures and rules make it hard to reward a good manager with } \\
\text { higher pay here. }\end{array}$} \\
\hline New York Survey & 1.56 & 3.31 & & 0.0000 & 0.5121 \\
\hline Florida Survey & 1.89 & 3.18 & & 0.0000 & 0.2926 \\
\hline Denver Survey & 1.43 & 3.28 & & 0.0000 & 0.4679 \\
\hline NASP III & 1.32 & & 2.63 & 0.0000 & 0.393 \\
\hline Illinois Survey & 1.27 & & 2.53 & 0.0000 & 0.373 \\
\hline Georgia Survey & 1.36 & & 2.96 & 0.0000 & 0.442 \\
\hline
\end{tabular}

Scores on the surveys are 1=Strongly Agree and 4=Strongly Disagree.

The differences found in the New York, Florida, and Denver surveys remained large even with introduction of numerous control variables.

Note: The NASP III, Illinois Survey, and Georgia Survey results are those reported in the present study. 
Table 2: Previous Findings on Differences between Public and Private Managers' Perceptions of Personnel Rules

\begin{tabular}{|c|c|c|}
\hline & Public & Private \\
\hline \multicolumn{3}{|l|}{ Ohio Survey } \\
\hline $\begin{array}{l}\text { If a manager is not pulling his or her weight, it is } \\
\text { difficult, as far as formal procedures are } \\
\text { concerned, for superiors to fire that manager. }\end{array}$ & $\begin{array}{l}83 \% \\
\text { True or } \\
\text { Very True }\end{array}$ & $\begin{array}{l}26 \% \\
\text { True or } \\
\text { Very True }\end{array}$ \\
\hline $\begin{array}{l}\text { The formal pay structures and rules make it hard } \\
\text { to reward a good manager with higher pay here }\end{array}$ & $\begin{array}{l}81 \% \\
\text { True or } \\
\text { Very True }\end{array}$ & $\begin{array}{l}20 \% \\
\text { True or } \\
\text { Very True }\end{array}$ \\
\hline \multicolumn{3}{|l|}{ New York Survey } \\
\hline $\begin{array}{l}\text { Even if a manager is a poor performer, formal } \\
\text { rules make it hard to remove him or her from the } \\
\text { organization }\end{array}$ & $\begin{array}{l}89.5 \% \\
\text { Agree or } \\
\text { Strongly Agree }\end{array}$ & $\begin{array}{l}8.7 \% \\
\text { Agree or } \\
\text { Strongly Agree }\end{array}$ \\
\hline $\begin{array}{l}\text { The formal pay structures and rules make it hard } \\
\text { to reward a good manager with higher pay here }\end{array}$ & $\begin{array}{l}86.1 \% \\
\text { Agree or } \\
\text { Strongly Agree }\end{array}$ & $\begin{array}{l}17.5 \% \\
\text { Agree or } \\
\text { Strongly Agree }\end{array}$ \\
\hline
\end{tabular}

Adapted from Rainey (1983) and Rainey, Pandey, \& Bozeman. (1995).

Note: The differences remained large even after introduction of numerous control variables.

\section{Table 3. Principal Components Analysis for Personnel Flexibility Items}

1. Because of the rules here, promotions are based mainly on performance (reverse)

2. Even if a manager is a poor performer, formal rules make it hard to remove him or her from the organization

3. The formal pay structures and rules make it hard to reward a good employee with higher pay here 
Table 4: Factor Analysis Work Motivation Items

\begin{tabular}{|l|c|c|}
\hline & Security & Advancement \\
\hline Opportunity for advancement within the organization's hierarchy & .427 & $\mathbf{. 6 2 0}$ \\
\hline Job Security & $\mathbf{. 7 6 3}$ & -.023 \\
\hline The organization's pension or retirement plan & $\mathbf{. 8 3 7}$ & .080 \\
\hline Desire for increased responsibility & -.015 & $\mathbf{. 8 3 7}$ \\
\hline Benefits (medical, insurance) & $\mathbf{. 8 5 0}$ & .076 \\
\hline Few, if any, alternative job offers & .393 &.- .413 \\
\hline
\end{tabular}

Extraction Method: Principal Component Analysis.

Rotation Method: Varimax with Kaiser Normalization.

Rotation converged in 3 iterations.

Dimensions represent $60.171 \%$ of the common variance in the initial correlation matrix

Table 5: Comparison of Means of Personnel Flexibility Items, by Sector

\begin{tabular}{lcccc}
\hline & $\begin{array}{c}\text { Mean } \\
\text { Public }\end{array}$ & $\begin{array}{c}\text { Mean } \\
\text { Nonprofit }\end{array}$ & $\begin{array}{c}\text { Sig. } \\
\text { Level }\end{array}$ & Eta2 \\
\hline $\begin{array}{l}\text { Even if a manager is a poor performer, formal rules make it hard to remove him or } \\
\text { her from the organization. }\end{array}$ & \multicolumn{4}{l}{} \\
\hline $\begin{array}{l}\text { Full Sample } \\
\text { Illinois Survey } \\
\text { Georgia Survey }\end{array}$ & 2.96 & 1.97 & 0.0000 & 0.214 \\
\hline $\begin{array}{l}\text { The formal pay structures and rules make it hard to reward a good manager } \\
\text { higher pay here. }\end{array}$ & 2.10 & 2.07 & 0.0000 & 0.249 \\
\hline $\begin{array}{l}\text { Full Sample } \\
\text { Illinois Survey }\end{array}$ & 3.68 & 2.37 & 0.0000 & 0.393 \\
Georgia Survey & 3.73 & 2.47 & 0.0000 & 0.373 \\
\hline Because of the rules here, promotions are based mainly on performance. & \\
\hline $\begin{array}{l}\text { Full Sample } \\
\text { Illinois Survey } \\
\text { Georgia Survey }\end{array}$ & 2.14 & 2.84 & 0.0000 & 1.04 \\
\hline
\end{tabular}

1=strongly disagree; $2=$ somewhat disagree; $3=$ =somewhat agree; 4=strongly agree 
Table 6: OLS Model Predicting Organizational Red Tape, by Sector

\begin{tabular}{|c|c|c|c|c|c|c|c|c|c|c|c|c|}
\hline & \multicolumn{4}{|c|}{ Full Model } & \multicolumn{4}{|c|}{ Nonprofit } & \multicolumn{4}{|c|}{ Public } \\
\hline & $\begin{array}{c}\text { Unstand. } \\
\text { Beta }\end{array}$ & $\begin{array}{c}\text { Std. } \\
\text { Error }\end{array}$ & $\begin{array}{c}\text { Stand. } \\
\text { Beta }\end{array}$ & & $\begin{array}{c}\text { Unstand. } \\
\text { Beta }\end{array}$ & $\begin{array}{l}\text { Std. } \\
\text { Error }\end{array}$ & $\begin{array}{c}\text { Stand. } \\
\text { Beta }\end{array}$ & & $\begin{array}{c}\text { Unstand. } \\
\text { Beta }\end{array}$ & $\begin{array}{l}\text { Std. } \\
\text { Error }\end{array}$ & $\begin{array}{c}\text { Stand. } \\
\text { Beta }\end{array}$ & \\
\hline Constant & 7.241 & 1.772 & & & 5.994 & 3.227 & & & 6.542 & 2.139 & & \\
\hline Nonprofit & -2.787 & 0.198 & -0.483 & $* * *$ & & & & & & & & \\
\hline Security Motivation & 0.288 & 0.083 & 0.107 & $* * *$ & 0.574 & 0.152 & 0.224 & $* * *$ & 0.060 & 0.098 & 0.025 & \\
\hline Career Advancement Motivation & -0.143 & 0.076 & -0.054 & $*$ & -0.046 & 0.153 & -0.016 & & -0.173 & 0.086 & -0.083 & $* *$ \\
\hline Desire to Serve Public & 0.054 & 0.082 & 0.018 & & 0.260 & 0.140 & 0.101 & $*$ & -0.091 & 0.103 & -0.036 & \\
\hline Previous job: Private Sector & 0.303 & 0.215 & 0.04 & & 0.405 & 0.350 & 0.066 & & 0.215 & 0.279 & 0.031 & \\
\hline Age of Respondent & 0.048 & 0.072 & 0.155 & & -0.013 & 0.128 & -0.044 & & 0.080 & 0.087 & 0.320 & \\
\hline Age Squared & 0.000 & 0.001 & -0.241 & & 0.000 & 0.001 & 0.029 & & -0.001 & 0.001 & -0.431 & \\
\hline Org Size: \#FTE & 3.91E-05 & 0.000 & 0.086 & $* * *$ & 0.000 & 0.000 & 0.014 & & 0.000 & 0.000 & 0.128 & $* * *$ \\
\hline Total Civic Activities & -0.117 & 0.05 & -0.065 & $* *$ & -0.376 & 0.106 & -0.199 & $* * *$ & 0.001 & 0.055 & 0.001 & \\
\hline Georgia & -1.132 & 0.154 & -0.211 & $* * *$ & -1.181 & 0.353 & -0.187 & $* * *$ & -1.033 & 0.168 & -0.243 & $* * *$ \\
\hline Female & -0.082 & 0.148 & -0.015 & & 0.136 & 0.300 & 0.026 & & -0.256 & 0.167 & -0.060 & \\
\hline Nonwhite & -0.364 & 0.213 & -0.047 & $*$ & 0.616 & 0.715 & 0.046 & & -0.424 & 0.212 & -0.077 & \\
\hline Current job: Manager & -0.086 & 0.26 & -0.014 & & -0.730 & 0.673 & -0.095 & & -0.004 & 0.276 & 0.000 & \\
\hline Current job: Tenure & -0.01 & 0.023 & -0.025 & & -0.081 & 0.072 & -0.208 & & 0.003 & 0.024 & 0.008 & \\
\hline Manager*Tenure & -0.013 & 0.026 & -0.031 & & 0.034 & 0.076 & 0.090 & & -0.008 & 0.027 & -0.024 & \\
\hline $\mathrm{p}<.10=*, \mathrm{p}<.05=* *, \mathrm{p}<.01=* * *$ & $\mathrm{~N}=956$ & & & & $\mathrm{~N}=295$ & & & & $\mathrm{~N}=660$ & & & \\
\hline $\mathrm{R}^{2}$ & 0.349 & & & & 0.221 & & & & 0.100 & & & \\
\hline Adjusted $\mathrm{R}^{2}$ & 0.337 & & & & 0.176 & & & & 0.078 & & & \\
\hline Std. Error of the Estimate & 2.172 & & & & 2.378 & & & & 2.033 & & & \\
\hline
\end{tabular}


Table 7: OLS Models predicting Personnel Flexibility Index, by Sector

\begin{tabular}{|c|c|c|c|c|c|c|c|c|c|c|c|}
\hline & \multicolumn{4}{|c|}{ Full Model } & \multicolumn{3}{|c|}{ Public } & \multicolumn{4}{|c|}{ Nonprofit } \\
\hline & $\begin{array}{c}\text { Unstand. } \\
\text { B } \\
\end{array}$ & SE & $\begin{array}{c}\text { Stand. } \\
\text { B }\end{array}$ & & $\begin{array}{c}\text { Unstand. } \\
\text { B }\end{array}$ & SE & $\begin{array}{c}\text { Stand. } \\
\text { B }\end{array}$ & $\begin{array}{c}\text { Unstand. } \\
\text { B } \\
\end{array}$ & SE & $\begin{array}{c}\text { Stand. } \\
\text { B }\end{array}$ & \\
\hline Constant & 12.007 & 1.351 & & & 11.076 & 1.574 & & 10.581 & 2.632 & & \\
\hline Nonprofit & -3.129 & 0.150 & -0.638 & $* * *$ & & & & & & & \\
\hline Security Motivation & 0.248 & 0.063 & 0.107 & $* * *$ & 0.105 & 0.072 & 0.056 & 0.449 & 0.127 & 0.215 & $* * *$ \\
\hline Career Advancement Motivation & -0.097 & 0.057 & -0.043 & $*$ & -0.086 & 0.063 & -0.053 & -0.143 & 0.125 & -0.065 & \\
\hline Desire to Serve Public & -0.095 & 0.062 & -0.038 & & -0.156 & 0.076 & $-0.079 * *$ & -0.036 & 0.113 & -0.018 & \\
\hline Financial Motivation & -0.045 & 0.081 & -0.014 & & -0.100 & 0.089 & -0.044 & 0.158 & 0.174 & 0.055 & \\
\hline Previous job: Private Sector & 0.430 & 0.164 & 0.066 & $* * *$ & 0.247 & 0.205 & 0.046 & 0.683 & 0.287 & 0.138 & $* *$ \\
\hline Age of Respondent & -0.018 & 0.055 & -0.068 & & 0.037 & 0.064 & 0.192 & -0.132 & 0.105 & -0.567 & \\
\hline Age Squared & 0.000 & 0.001 & -0.026 & & -0.001 & 0.001 & -0.316 & 0.001 & 0.001 & 0.515 & \\
\hline Org Size: \#FTE & 0.000 & 0.000 & 0.049 & $*$ & 0.000 & 0.000 & $0.076 * *$ & 0.000 & 0.000 & 0.071 & \\
\hline Total Civic Activities & -0.068 & 0.038 & -0.045 & $*$ & -0.023 & 0.041 & -0.021 & -0.166 & 0.087 & -0.110 & $*$ \\
\hline Georgia & -1.131 & 0.117 & -0.249 & $* * *$ & -1.109 & 0.123 & $-0.340 * * *$ & -1.023 & 0.291 & -0.200 & $* * *$ \\
\hline Female & 0.156 & 0.112 & 0.034 & & 0.016 & 0.122 & 0.005 & 0.392 & 0.243 & 0.094 & \\
\hline Nonwhite & -0.361 & 0.160 & -0.055 & $* *$ & -0.366 & 0.154 & $-0.087 * * *$ & 0.007 & 0.600 & 0.001 & \\
\hline Current job: Promotion & -0.130 & 0.120 & -0.029 & & -0.254 & 0.132 & $\mathbf{- 0 . 0 7 7} * *$ & 0.217 & 0.256 & 0.050 & \\
\hline Current job: Manager & -0.593 & 0.196 & -0.117 & $* * *$ & -0.527 & 0.203 & $-0.153 * * *$ & -0.676 & 0.543 & -0.110 & \\
\hline Current job: Tenure & -0.016 & 0.018 & -0.046 & & -0.014 & 0.017 & -0.056 & -0.016 & 0.057 & -0.050 & \\
\hline Manager*Tenure & 0.027 & 0.020 & 0.080 & & 0.030 & 0.020 & 0.115 & 0.020 & 0.061 & 0.067 & \\
\hline $\mathrm{P}<.10=*, \mathrm{p}<.05=* *, \mathrm{p}<.01=* * *$ & $\mathrm{~N}=953$ & & & & $\mathrm{~N}=665$ & & & $\mathrm{~N}=287$ & & & \\
\hline  & 0.692 & & & & 0.418 & & & 0.466 & & & \\
\hline $\mathrm{R}^{2}$ & 0.479 & & & & 0.174 & & & 0.217 & & & \\
\hline Adj. $\mathrm{R}^{2}$ & 0.469 & & & & 0.154 & & & 0.171 & & & \\
\hline SEE & 1.642 & & & & 1.496 & & & 1.905 & & & \\
\hline
\end{tabular}

Note: The Personnel Flexibility Index ranges from (3) low personnel constraints through (12) high perceived personnel constraints. Lower scores indicate perceptions of higher levels of personnel flexibility. 


\section{Appendix I}

\section{NASP-III Approach}

The National Administration Studies Project (NASP) aims to increase our empirical knowledge of public management and administration. NASP-III is an attempt to blend the goals of NASP-I and II while addressing a few new themes of its own. NASP-III collected data on public and nonprofit managers in Georgia and Illinois. Unlike NASP-II, which focused on a single functional agency (health and human services), the NASP-III sample includes managers from agencies and organizations of numerous functions.

The population of managers in Georgia was drawn from the Georgia Department of Audits (DoA) comprehensive list of state employees who were on state agency payrolls during the 2003/2004 fiscal year. We removed employees at technical colleges, commissions, authorities, the office of the governor, and institutions from the judicial or legislative branch. In addition we removed employees at institutions with less than 20 employees. The population included any job titles coded as "director" "coordinator" “officials or manager” and "professionals" under the pay grade of 017 and all individuals with a pay grade of 017 or higher. The resulting population included 6,164 Georgia managers.

The population of managers in Illinois was developed through a Freedom of Information Act request for a list of all state employees designated as either "senior public service administrators" or "public service administrators." This list included information on 5,461 state employees, including name, agency, and county.

\section{Survey Administration}

The survey administration included a pre-contact letter, Wave I survey with letter, follow-up postcard mailing, Wave II mailing, follow-up contacts by phone call and email, and a final Wave III mailing. The survey was closed January 1, 2006. We received 549 responses in Wave I, 135 in Wave II, and 111 in Wave III.

\section{Response Rates}

Though we began with a sample of 2000 public sector respondents our sample was reduced to 1849 (912 Georgia, 937 Illinois) because of respondents who had retired (16 cases) or are longer working for the agency (135 cases). The survey was closed with 432 responses from Georgia and 358 from Illinois. 


\section{Appendix II: Descriptive Statistics}

\begin{tabular}{lrrrrr}
\hline & N & Min & Max & Mean & $\begin{array}{c}\text { Standard } \\
\text { Deviation }\end{array}$ \\
\hline Red Tape Scale & 1193 & 0 & 10 & 6.03 & 2.683 \\
\hline Performance-based Promotions & 1193 & 1 & 4 & 2.38 & 1.013 \\
\hline Performance-based Removal & 1195 & 1 & 4 & 2.61 & 1.009 \\
\hline Performance-based Rewards & 1199 & 1 & 4 & 3.22 & 1.001 \\
\hline Security Motivation & 1177 & -3 & 2 & .00 & 1.000 \\
\hline Career Advancement Motivation & 1177 & -3 & 2 & .00 & 1.000 \\
\hline Desire to Serve Public & 1199 & 1 & 4 & 3.17 & .913 \\
\hline Salary Motivation & 1201 & 1 & 4 & 3.28 & .726 \\
\hline Age of respondents & 1204 & 23 & 81 & 49.44 & 8.913 \\
\hline Age Squared & 1204 & 529 & 6561 & 2523 & 870.765 \\
\hline Organization age (2007- year) & 1122 & 2 & 209 & 59.55 & 37.384 \\
\hline Total Civic Activities & 1219 & 0 & 8 & 2.67 & 1.457 \\
\hline Georgia & 1220 & 0 & 1 & .44 & .497 \\
\hline Nonprofit Sector & 1191 & 0 & 1 & .33 & .472 \\
\hline Female & 1208 & 0 & 1 & .45 & .498 \\
\hline Nonwhite & 1171 & 0 & 1 & .14 & .348 \\
\hline \# employees supervised, if any & 1057 & 0 & 1200 & 21.12 & 73.084 \\
\hline Current job: Promotion & 1219 & 0 & 1 & .47 & .500 \\
\hline Current job: Manager & 1219 & 0 & 1 & .71 & .456 \\
\hline Current job: Tenure & 1157 & 0 & 39 & 7.63 & 6.489 \\
\hline Interaction manager*tenure & 1192 & 0 & 39 & 5.37 & 6.561 \\
\hline Last job was in private sector & 1210 & 0 & 1 & .16 & .371 \\
\hline & & & & & \\
\hline
\end{tabular}




\section{Appendix III}

\section{Comparison of Means of Personnel Flexibility Items, by Sector and Organizational Function}

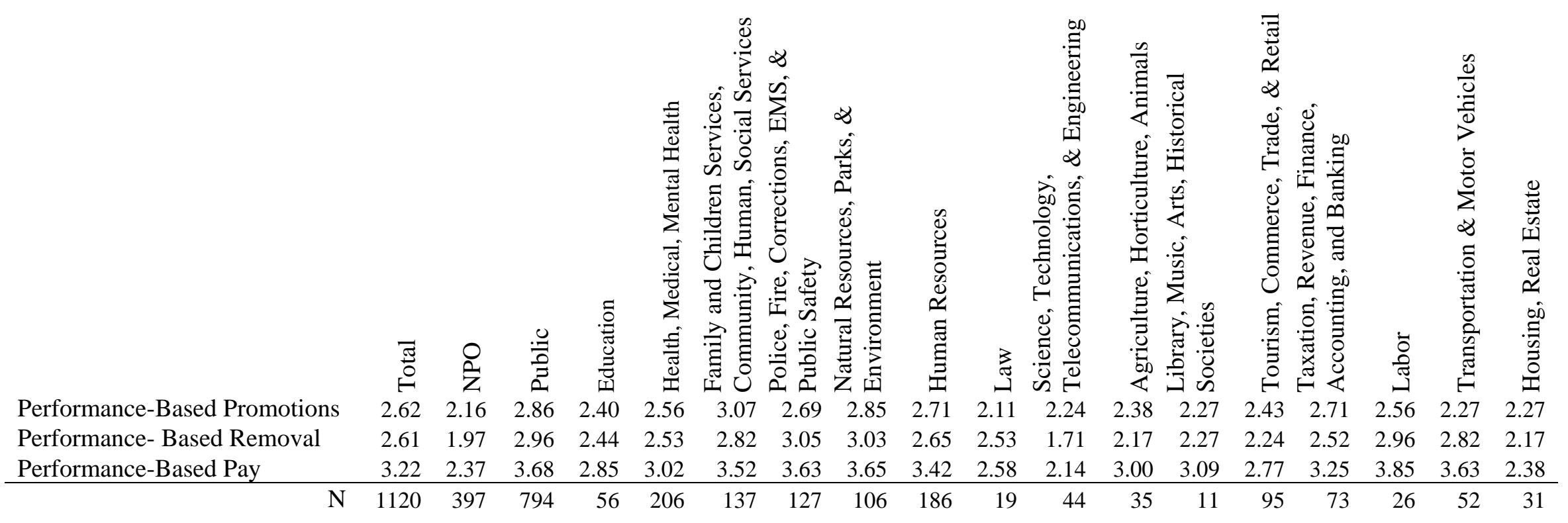




\section{References}

Alchian, Armen A., and Harold Demsetz. 1972. Production, information costs, and economic organization. American Economic Review 62: 777-799.

Anheier, Helmut K., and Wolfgang Seibel, eds. 1990. The third sector: Comparative studies of nonprofit organizations. New York: de Gruyter.

Baldwin, J. Norman. 1990. Perceptions of public versus private sector personnel and informal red tape and their impact on motivation. American Review of Public Administration 20 (1):7-28.

Balfour, Danny L., and Barton Wechsler. 1990. Organizational commitment: A reconceptualization and empirical test of public-private differences. Review of Public Personnel Administration 10 (3):23-40.

Balfour, Danny L., and Barton Wechsler. 1991. Commitment, performance, and productivity in public organizations. Public Productivity \& Management Review 14 (4):355-367.

Ballendstedt, Brittany R. 2007. “Pay reform, recruiting cited as top personnel challenges. Govexec.com, July 19.

Berman, Evan M., and Jonathan P. West. 1998. Productivity enhancement efforts in public and nonprofit organisations. Public Productivity \& Management Review 22 (2):207-219.

Borzaga, Carlo, and Ermanno Tortia. 2006. Worker motivations, job satisfaction, and loyalty in public and nonprofit social services. Nonprofit and Voluntary Sector Quarterly 35 (2):225-248.

Boardman, P. Craig, Barry Bozeman, and Branco Ponomariov. (in press). Private sector imprinting: An examination of the impacts of private sector job experience on public managers' work attitudes. Public Administration Review.

Boyne, George. 2002. Public and private management: What's the difference? Journal of Management Studies 39 (1): 97-122.

Boyne, George, Gene A., Brewer, and Richard Walker. 2006. Strategy, red tape, and organizational performance: An empirical odyssey. Paper presented at A Performing Public Sector: The Second TransAtlantic Dialogue, Katholieke Universiteit, Leuven, Belgium, 1-3 June 2006.

Bozeman, Barry. 2000. Bureaucracy and Red tape. Upper Saddle River, NJ: Prentice Hall.

Bozeman, Barry. 1987. All organizations are public. San Francisco: Jossey-Bass.

Bozeman, Barry, and Patrick Scott. 1996. Bureaucratic red tape and formalization: Untangling conceptual knots. American Review of Public Administration, 26(1): 1-17. 
Bozeman, Barry, and Stuart Bretschneider. 1994. The "publicness puzzle" in organization theory: A test of alternative explanations of differences between public and private organizations. Journal of Public Administration Research and Theory 4 (2):197-223.

Bretschneider, Stuart. 1990. Management information systems in public and private organizations: An empirical test. Public Administration Review 50 (5):536-545.

Brewer, Gene, and Richard Walker. 2005. The impact of red tape on governmental performance: An empirical analysis. Prepared for delivery at the Association for Public Policy Analysis and Management (APPAM) Twenty-Seventh Annual Research Conference, Washington DC, November 3-5, 2005.

Brewer, Gene, and Richard Walker. 2006. Can managers reduce red tape? An empirical analysis of environmental constraints and internal management. Prepared for delivery at the 2006 Annual Meeting of the American Political Science Association, Philadelphia, Pennsylvania, August 31 - September 3.

Bridges, William P., and Wayne J. Villamez. 1994. The employment relationship: causes, and consequences of modern personnel administration. New York: Plenum Studies.

Brudney, Jeffrey L. 1998a. Voluntarism. In International encyclopedia of public policy and administration, ed. J. M. Shafritz. Boulder, CO.: Westview Press.

Brudney, Jeffrey L. 1998b. Volunteer administration. In International Encyclopedia of Public Policy and Administration, ed. J. M. Shafritz. Boulder, CO.: Westview Press.

Buchanan, Bruce. 1975. Red tape and the service ethic: Some unexpected differences between public and private managers. Administration \& Society 6 (4):423-444.

Corder, Kevin. 2001. Acquiring new technology - Comparing nonprofit and public sector agencies. Administration \& Society 33 (2):194-219.

Crewson, Phillip. E. 1995. The public service ethic. American University, Washington, D.C.

Dahl, Robert A. and Charles Lindblom. 1953. Politics, economics, and welfare. New York: HarperCollins.

De Alessi, L. 1980. The economics of property rights: A review of the evidence. In Research in Law and Economics, ed. R. O. Zerbe. Vol. 2. Greenwich, Connecticut: JAI Press.

De Graaf, Gjalt, and Zeger van der Wal. 2008. On value differences experienced by sector switchers. Administration \& Society 40 (1):79-103.

Dehart-Davis, Leisha. 2007. The unbureaucratic personality. Public Administration Review 67 (5):892903.

DeHart-Davis, Leisha, and Sanjay Pandey. 2005. Red tape and public employees: Does perceived rule 
dysfunction alienate managers? Journal of Public Administration Research and Theory 15 (1): 133-148.

Dodd-McCue, Diane, and Gail Wright. 1996. Men, women, and attitudinal commitment: The effects of workplace experiences and socialization. Human Relations 49 (8):1065-1091.

Down, Anthony. 1967. Inside Bureaucracy. Boston: Little, Brown.

Eggleston, Karen, and Richard Zeckhauser. 2002. Government contracting for health care. In J. D. Donahue \& J. S. Nye, Jr. (Eds.), Market-based governance (pp. 29-65). Washington, DC: Brookings Institution Press.

Feeney, Mary K. 2008. Sector perceptions among state-level public managers. Journal of Public Administration Research and Theory 18(3):465-494.

Feeney, Mary K., and Dehart-Davis, Leisha. 2009. Bureaucracy and public employee behavior: A case of local government. Review of Public Personnel Administration OnlineFirst, published on March 11, 2009 as doi:10.1177/0734371X09333201.

Feiock, Richard C., and Hee-Soun Jang. 2007. The role of nonprofit contractors in the delivery of local services. Nonprofit Sector Research Fund. Working Paper Series. Washington, DC: The Aspen Institute.

Gore, Al. 1993. From red tape to results: Creating a government that works better \& costs less. Report of the National Performance Review. Pittsburgh, PA: U.S. Government Printing Office.

Hall, Peter Dobkin. 1992. Inventing the nonprofit sector and other essays on philanthropy, voluntarism, and nonprofit organizations. Baltimore: Johns Hopkins University Press.

Harpaz, Itzhak, and Itzhak Snir. 2003. Workaholism: Its definition and nature. Human Relations 56 (3): 291-319.

Hays, Steven W., and Jessica E. Sowa. 2006. A broader look at the 'accountability' movement: Some grim realities in state civil service systems. Review of Public Personnel Administration 26 (2):102-117.

Ingraham, Patricia W. 1993. Of pigs in pokes and policy diffusion: Another look at pay-forperformance. Public Administration Review 53:348-356.

Irvin, Renée A. 2005. State regulation of nonprofit organizations: Accountability regardless of outcome. Nonprofit and Voluntary Sector Quarterly 34 (2):161-178.

Izraeli, Dafna N. 1990. Human resources and labor relations in Israel. New horizons. In Human resources and labor relations in Israel, ed. A. Globerson, A. Galin and E. Rozenshtein. Tel Aviv, Israel: Ramot. 
Jurkiewicz, Carole L., Tom K. Massey Jr., and Roger G. Brown. 1998 Motivation in public and private organizations: A comparative study. Public Productivity \& Management Review 21 (3):230-250.

Kalleberg, Arne L., Peter V. Marsden, Jeremy Reynolds, and David Knoke. 2006. Beyond profit? Sectoral differences in high-performance work practices. Work and Occupations 33 (3):271-302.

Kanuk and Berenson. 1975. Mail surveys and response rates: A literature review. Journal of Marketing Research 12: 440-453.

Kellough, J.Edward, and H. Lu. 1993. The paradox of merit pay in the public sector: Persistence of a problematic procedure. Review of Public Personnel Administration 13(2):45-64.

Kettl, Donald F. 1993. Sharing power: Public governance and private markets. Washington, D.C: Brookings Institution.

Lan, Zhiyong, and Hal G. Rainey. 1992. Goals, rules, and effectiveness in public, private, and hybrid organizations: More evidence on frequent assertions about differences. Journal of Public Administration Research and Theory 2 (1):5-28.

Light, Paul C. 2002. The content of their character: The state of the nonprofit workforce. Nonprofit Quarterly, 9 (3): 6-16.

Lyons, Sean T., Linda E. Duxbury, and Christopher A. Higgins. 2006. Motivation and performance: A comparison of the values and commitment of private sector, public sector, and parapublic sector employees. Public Administration Review 66 (4):605-618.

Macy, John W. 1971. Public service: The human side of government. New York: Harper \& Row.

Mirvis, Philip H., and Edward J. Hackett. 1983 Work and work force characteristics in the nonprofit sector. Monthly Labor Review 106 (4): 3-12.

Moon, Jae M., and Stuart Bretschneider. 2002. Does the perception of red tape constrain IT innovativeness in organizations? Unexpected results from a simultaneous equation model and implications. Journal of Public Administration Research and Theory 12 (2):273-291.

Moynihan, Donald P., and Sanjay K. Pandey. 2007. The role of organizations in fostering public service motivation. Public Administration Review 67: 40-53.

Pandey, Sanjay K., and Donald P. Moynihan. 2006. Bureaucratic red tape and organizational performance: Testing the moderating role of culture and political support. In Public Service Performance, ed. G. A. Boyne, K. J. Meier, L. J. O'Toole and R. M. Walker. Cambridge, England: Cambridge University Press.

Pandey, Sanjay K., and Patrick G. Scott. 2002. Red tape: A review and assessment of concepts and measures. Journal of Public Administration Research and Theory 12 (4):553-580. 
Pandey, Sanjay K., and Eric W. Welch. 2005. Beyond stereotypes: A multistage model of managerial perceptions of red tape. Administration \& Society 37(5): 542-575.

Perry, James L., and Hondeghem, Annie, eds. 2008a. Motivation in public management: The call of public service. Oxford: Oxford University Press,

Perry, James L., and Annie Hondeghem. 2008b. "Building theory and empirical evidence about public service motivation.” International Public Management Journal 11(1): 3-12.

Pugh, Derek S., Hickson, David J., Hinings, Christopher R., \& Turner, C. 1969. The Context of Organization Structures. Administrative Science Quarterly, 14(1): 91-114.

Rainey, Hal G. 1983. Public agencies and private firms: Incentive structures, goals and individual roles. Administration \& Society 15 (2):207-242.

Rainey, Hal G., Rex Facer, and Barry Bozeman. 1995. Repeated findings of sharp differences between public and private managers' perceptions of personnel rules. A Paper presented at the Annual Meeting of the American Political Science Association. Chicago.

Rainey, Hal G., Sanjay Pandey, and Barry Bozeman. 1995. Research note - Public and private managers perceptions of red tape. Public Administration Review 55 (6):567-574.

Rawls, James R., Robert A. Ullrich, and Oscar Tivis Jr. Nelson. 1975. A comparison of managers entering or reentering the profit and nonprofit sectors. The Academy of Management Journal 18 (3):616-623.

Rotolo, Thomas, and John Wilson. 2006. Employment sector and volunteering: The contribution of nonprofit and public sector workers to the volunteer labor force. Sociological Quarterly 47 (1):21-40.

Salamon, Lester M. 1998. Nonprofit organizations: America's invisible sector. Issues of Democracy 3 (1). http://www.usia.gov/journals/itdr/0198/ijde/salamon.htm.

Schneider, Benjamin. 1987. The people make the place. Personnel Psychology 40:437-53.

Schneider, Benjamin, Harold W. Goldstein, and D. Brent Smith. 1995. The ASA framework: An update. Personnel Psychology 48:747-73.

Scott, Patrick G., and Sanjay K. Pandey. 2005. Red tape and public service motivation: Findings from a national survey of managers in health and human services agencies. Review of Public Personnel Administration 25 (2):155-180.

Simon, Herbert A. 1995. Organizations and markets. Journal of Public Administration Research and Theory 5: 273-294.

Smith, Steven R., and Michael Lipsky. 1993. Nonprofits for hire: The welfare state in the age of contracting. Cambridge, Mass.: Harvard University Press. 
Steinhaus, Carol S., and James L. Perry. 1996. Organizational commitment: Does sector matter? . Public Productivity \& Management Review 19 (3):278-288.

Thompson, James D. 1962. Common and uncommon elements in administration. Social Welfare Forum 89: 181-201.

Thompson, James R., and Hal G. Rainey. 2003.Modernizing human resource management in the federal government: The IRS model. Arlington, Va.: IBM Endowment for the Business of Government.

U. S. Office of Personnel Management. 1999. Federal workforce statistics: Workforce and trends as of May, 1999. Washington, DC: U.S. Office of Personnel Management.

Walters, Jonathon. 2002. Life after civil service reform: The Texas, Georgia, and Florida experiences. Arlington, VA: IBM Endowment for the Business of Government.

Warwick, Donald P. 1975. A theory of public bureaucracy. Cambridge, MA: Harvard University Press.

Weisbrod, Burton A. 1987. The voluntary nonprofit sector. Lexington, MA: D. C. Heath \& Co.

—. 1988. The nonprofit economy. Cambridge, MA: Harvard University Press.

Welch, Eric W., and Sanjay K. Pandey. 2007. E-Government and bureaucracy: Toward a better understanding of intranet implementation and its effect on red tape. Journal of Public Administration Research and Theory 17:379-404.

Wilson, James Q. 1989. Bureaucracy. New York. Basic Books.

Wittmer, Dennis, and David Coursey. 1996. Ethical work climates: Comparing top managers in public and private organizations. Journal of Public Administration Research and Theory 6 (4):559-572. 